\title{
Původní práce
}

\section{Longitudinální studie zaměřená na oseointegraci implantátů a změnu kvality života u adolescentních pacientů}

(Původní práce)

\section{Longitudinal Study Focused on Dental Implant Osseointegration and Quality of Life by Adolescent Patients}

\author{
(Original Article)
}

Papež J.', Dostálová T.', Kứž P. ${ }^{1}$, Polášková S. ${ }^{2}$, Feberová J. ${ }^{2}$, Štěpánek L. ${ }^{2}$

'Stomatologická klinika dětí a dospělých 2. LF UK a FN Motol, Praha

2Ústav vědeckých informací, 2. LF UK a FN Motol, Praha

Věnováno prof. MUDr. Tatjaně Dostálové, DrSc., MBA k významnému životnímu jubileu

\section{SOUHRN}

Předmět sdělení: S traumatickými ztrátami zubů a agenezí se u adolescentních pacientů setkáváme často. $\checkmark$ dnešní době využíváme k rekonstrukci chrupu především dentální implantáty, které však je možné aplikovat až po ukončení vývoje obličejového skeletu. Úspěšná rehabilitace pacienta za podpory implantátů závisí nejen na správné indikaci a optimálním zavedení, ale také na funkční a psychosociální adaptaci jedince. Kvalita života je výrazně ovlivněna spokojeností či nespokojeností se zubním ošetřením.

Cíle této studie jsou dva. Za prvé zhodnotit dlouhodobou léčbu dospívajících/mladých dospělých pacientů po multidisciplinární léčbě, včetně zavedení implantátů s CAD CAM protetickou rekonstrukcí chrupu. Za druhé vyhodnotit změny $v$ kvalitě života před zavedením a po zavedení dentálního implantátu.

Materiál a metoda: Základ studie tvořil soubor 73 implantátů (Osseo Speed ${ }^{\mathrm{TM}}$ ASTRA TECH Implant System ${ }^{\mathrm{TM}}$, Ltd, UK) u pacientů v rozmezí 16 až 23 let (13 mužů a 20 žen; průměrný věk byl 20,4 let). Pacienti byli sledováni po dobu šesti let. Kontrolovali jsme jejich estetický vzhled se zaměřením na tvar a polohu korunek i vývoj rekonstrukce na základě parodontálního biotypu. V RTG obrazu jsme hodnotili polohu mikrozávitů v krčkové oblasti implantátů, tedy vývoj oseointegrace implantátu z hlediska apozice či resorpce kosti. Současně všichni pacienti zapojení do studie vyplnili anonymně dotazník zjištující kvalitu života, který byl zaměřen na jejich orální zdraví a byl vytvořen na základě dotazníku Geriatric Oral Health Assessment Index. Jednotlivé výsledky všech otázek dotazníku zaznamenané před implantací a po ní byly porovnány pro každou otázku a výsledky byly hodnoceny pomocí Wilcoxonova párového testu.

Výsledky a závěr: Úspěšné dlouhodobé výsledky závisí především na stabilní oseointegraci, tedy procesu, při kterém dochází k remodelaci případně přírůstku kostní hmoty v oblasti krčkového uzávěru implantátu. Z naší studie je zřejmé, že apozice nebo resorpce kostní hmoty v okolí krčkového uzávěru implantátu přímo souvisí s vrstvou a kvalitou okolní kosti přítomné v místě zaváděného implantátu. Implantáty o prưměru 3-4,5 mm, které jsou cirkulárně obklopeny vrstvou 2-3 mm kosti, vykázaly statisticky významný nárůst kostní hmoty. Důraz u mladých pacientů musí být kladen na ukončení vývoje obličejového skeletu a na individuální provedení suprastruktur za použití CAD CAM techniky. Naše studie také prokázala, že vnímaní estetiky, funkce, též rozmělňování potravy nebo fonace, přímo souvisí s rehabilitací chrupu včetně zavedení implantátů. Subjektivní spokojenost pacienta i pozitivní reakce okolí měly přímý vliv na zlepšení celkové kvality života jak osobního, tak společenského i pracovního. Co je neměnné, je vnímání chuti, které s celkovou funkční rekonstrukcí pochopitelně nesouvisí. 


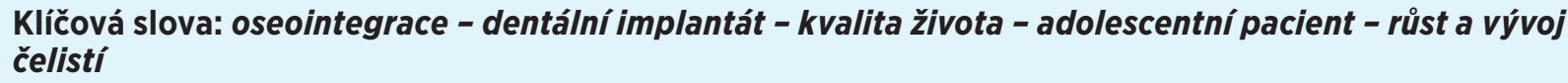

Objectives: By adolescent patients we can often meet with traumatic tooth loss and anodontia. Dental care of adolescent patients without own teeth, is not easy. Nowadays we use for reconstruction of teeth especially dental implants. Anthropological age determination for implant insertion is important and prosthodontic methods can be often applied only after multidisciplinary therapy. The successful rehabilitation of the patient with dental implants depends on correct indication, optimal implant insertion, functional and psychosocial adaptation. Quality of life is significantly influenced by satisfaction or dissatisfaction with dental treatment.

The aims of this study are twofold. Firstly, to evaluate the long term treatment of adolescent/young adult patients after multidisciplinary therapy, including implants insertion and CAD CAM prosthetic reconstruction. Secondly, to assess changes in quality of life before and after insertion of the dental implant.

Material and methods: A prospective study of 73 implants (Osseo Speed ${ }^{\text {TM }}$ ASTRA TECH Implant System ${ }^{\text {TM }}$, Ltd, UK) was prepared. The patients at implants surgery ranged from 16 to 23 years of age (13 men and 20 women; average age 20.4 years). The patients were followed up for a 6 -year period. The aesthetic appearance was checked mainly from the point of view of vertical position of the framework, loss of bone marginal support, patient satisfaction, and quality of life after patient rehabilitation. Also, the effect of microthread on the maintenance of marginal bone level was evaluated. All patients involved in the study completed an anonymous questionnaire investigating the quality of life, which was focused on their oral health and was created on the basis of a questionnaire Geriatric Oral Health Assessment Index. Individual scores of all questions of the questionnaire recorded before and after implantation were compared for each question. The significance of these differences was assessed using Wilcoxon signed-rank tests.

Results and conclusions: Successful long-term results depend mainly on stable osseointegration, the same or increasing bone height in the cervical cap. The implants with a diameter of 3-4.5 mm, which are surrounded 2-3 mm bone showed statistically significant bone level increase. The emphasis in young patients should be placed on completion of the development of the facial skeleton and the superstructure on individual designs using CAD CAM techniques. Our study showed that function, speech, esthetics, self-image was directly connected with multidisciplinary therapy including implant insertion. Quality of life is markedly affected by the amount of satisfaction or dissatisfaction with their dental therapy. Taste sensation of course had no influence on implants presence. Implants presence of course had no influence on taste sensation.

Keywords: osseointegration - dental implant - quality of life - adolescent patient - growth and evolution of mandible and maxilla

\section{ÚVOD}

Příčina ztráty stálých zubů u adolescentního pacienta může mít různou etiologii. Nejčastěji je způsobena traumatem (úrazy v orofaciální oblasti), genetickými anomáliemi (hypodoncie, oligodoncie, anodoncie) a značný vliv má zubní kaz. Zuby v okolí defektu bývají zpravidla intaktní. Jejich preparací na fixní protetické práce dochází k snížení biologického faktoru. Pokud defekt v místě chybějícího zubu umožní zavedení implantátu, pak by tento typ ošetření měl být preferován před dalšími možnostmi rekonstrukce chrupu, jako je například zhotovení fixního můstku či některého $\mathrm{z}$ typů částečných snímatelných náhrad.
Definitivní rehabilitace chrupu za podpory implantátů u mladého pacienta je možná až při splnění následujících podmínek: pacient musí mít ukončen vývoj obličejového skeletu, sanovaný chrup, výbornou ústní hygienu, všechny ortodontické anomálie musí být předléčeny.

Růst a vývoj čelistí je proces limitující zavedení dentálního implantátu. Zatímco neurokranium (mozková část lebky) dokončí vývoj okolo čtvrtého roku života jedince, viscerokranium (obličejová část lebky) se mũže formovat ještě dalších 20 let. Pokud je plánováno zavedení dentálního implantátu u dětského pacienta, je nutné si uvědomit, že spojení dentální implantát - kost je pevně dané a nemůže tedy měnit polohu v průběhu růstu čelistí. Dentální 

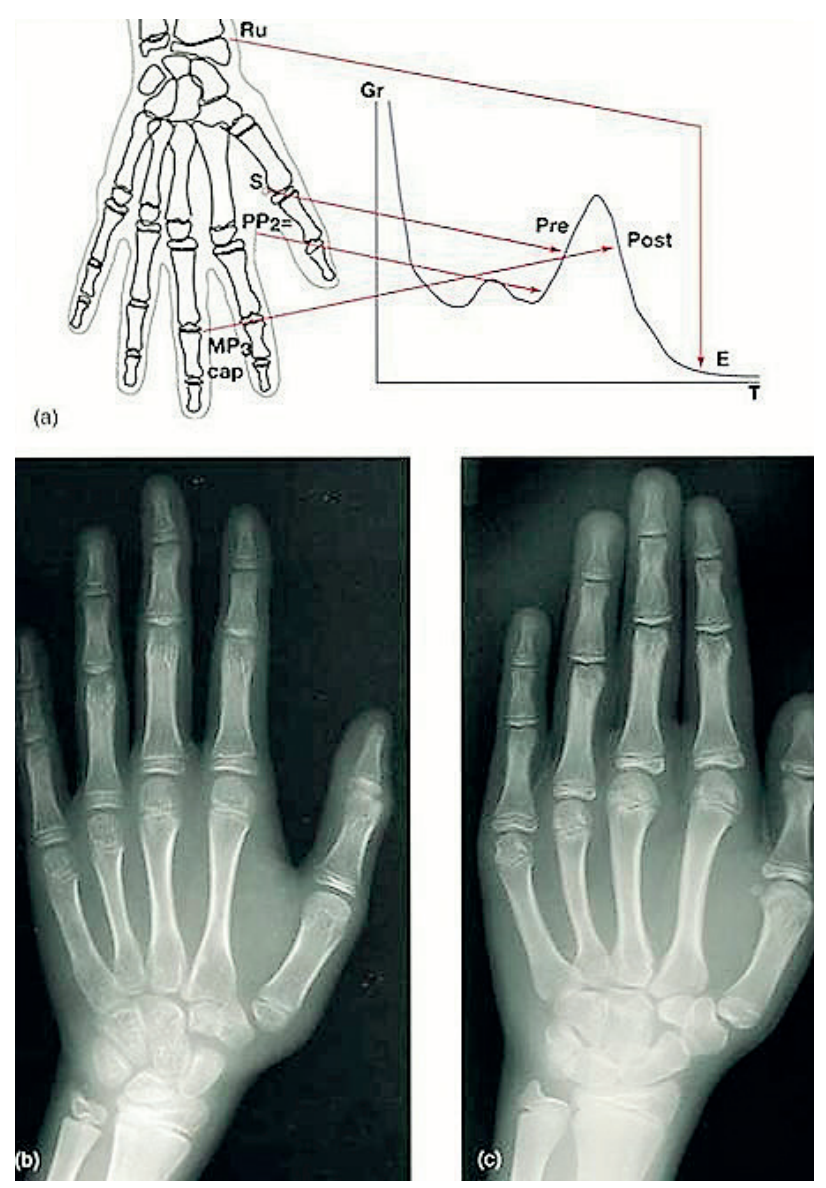

Obr. 1 RTG snímky zápěstí, ruky: na RTG posuzujeme distální epifýzu radia a ulny, třetí a pátý metakarp, proximální, středni a distální falangy prvního, třetího a pátého prstu a sedm karpálních kostí. Na obrázku je graf schematicky znázorňující růst $(\mathrm{Gr})$ v čase (T)

(a) Rentgenový snímek zápěstí - ruky se využívá k sestrojení růstové křivky. Sezamová kůstka (S) palce začíná obvykle kalcifikovat v průběhu akcelerační fáze pubertálního růstového spurtu (PRE). Protože růst bude ještě tálního růstového spurtu (PRE). Protože růst bude ještě implantátu. Uzavírání středních falangů prostředníčku ruky (MP3cap) obvykle nastává po maximálním růstovém spurtu a indikuje zpomalení pubertálního růstového spurtu (postpubertální POST). Tento jev koreluje u dívek se začátkem menstruace a u chlapců se změnou hlasu. Od doby, kdy pubertální růst je $z$ většiny ukončen, je možné začít uvažovat o zavedení implantátu. (Op Heij, G. D., Opdebeeck, H., Van Steenberghe, D., Quirynen, M.: Age as compromising factor for implant insertion. Periodontol. 2000, 2003 , roč. 33

č. 1, s. 172-184)

(b) Rentgenový snímek zápěstí dítěte. PP2 = vývoj kosti je $v$ počátečním stadiu růstu

(c) Rentgenový snímek zápěstí dítěte. Mpcap = indikuje, že maximální rychlost růstu je ukončena, ale skletální růst ještě není ukončen a erupce zubů je tak možná

implantáty mohou rušit normální vývoj čelistí. Pro lepší pochopení si musíme uvědomit, že maxila a mandibula se vyvíjejí ve třech osách, kdy nejdříve dochází k růstu transverzálně, následně sagitálně a nakonec vertikálně. Iseri a Solow [8] ve své studii prokázali, že mezi 15. a 20. rokem života dochází k vertikálnímu posunu zubů až o $5 \mathrm{~mm}$. Ve studii zaměřené na sledování implantátů ve frontálním úseku horní čelisti zavedených u adolescentních pacientů bylo zjištěno, že implantáty opatřené suprakonstrukcí se mohou dostat do infraokluze i v případě dokončeného skeletálního vývoje a přítomnosti všech zubů [15]. Z toho důvodu by měla být implantace ve frontálním úseku horní čelisti odložena do doby, kdy lze prokázat ukončený vývoj skeletu a čelistí. U dívek dochází k ukončení vývoje zpravidla dřive než u chlapců, a to ve věku kolem 15 let. Chlapci pak ukončují skeletální růst obvykle kolem 17. roku. Skeletální růst a jeho ukončení lze hodnotit pomocí několika biologických faktorũ: zvýšení tělesné výšky, zrání zápěstních kůstek a ruky, vývoj zubů a jejich erupce, změn hlasu, menstruace. Kostní věk reprezentuje chronologický věk, v němž dané skóre kostní zralosti je 50 percentil. Pokud v současnosti chceme stanovit biologický vývoj dítěte, tak nejpřesnější metodou je stanovení tzv. kostního věku [9]. Růstové změny kostí, které se vyskytují u vyvíjejících se jedinců, jsou u všech podobné a proměnný je jen čas, v němž k těmto změnám dochází. Každé osifikační centrum prochází určitým počtem morfologických stádií, jejichž posouzení je základem pro určení stupně kostní zralosti. Všechna centra kostní zralosti mohou být velmi snadno identifikována na rentgenovém snímku ruky, který je pro daný účel nejvíce informativní a snadno dostupným oddílem kostry.

V současnosti nejpřesnější metodou stanovení kostního věku je metoda TW2, vytvořená Brity

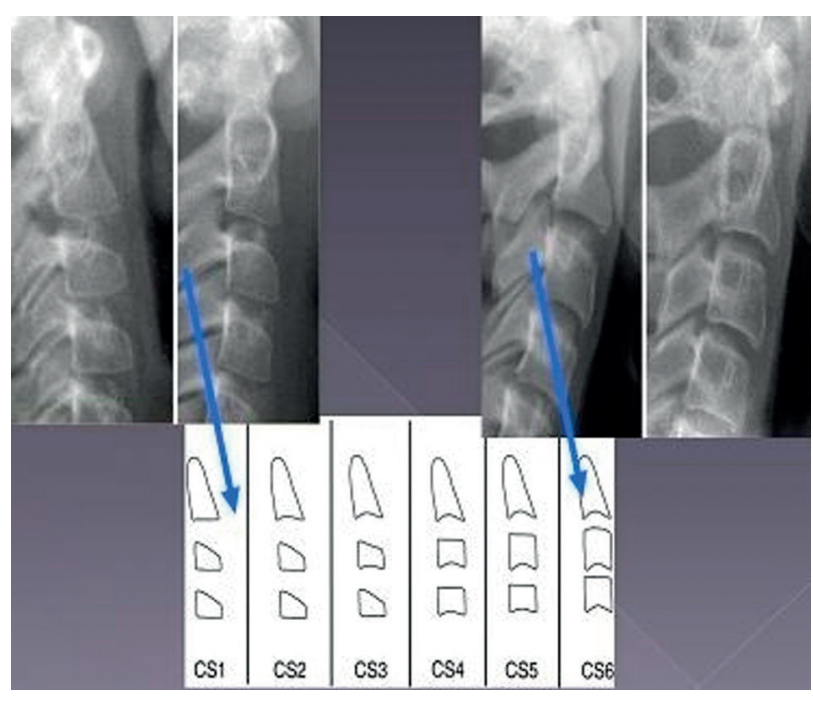

Obr. 2 Na kefalogramu se určuje stadium osifikace obratlů krční páteře u obratlů C2,C3 a C4 za využití metody CVMI Hassela a Farmana. (Hassel, B. Farman, A.G.: Skeletal maturation evaluation using cervical vertebrae. Am. J. Orthod. Dentofacial Orthop. 1995, roč. 107, č. 1, s. 58-65)
PRAKTICKÉ ZUBNÍ LÉKAŘSTVí, ročník 63 , 2015, 4 , 2015,4 s. $45-52$ 
Tannerem a Whitehousem na základě longitudinálního rentgenového sledování 3000 britských chlapců a dívek (1975) [14]. Metoda TW2 je založena na hodnocení tvaru, velikosti a prostorových vztahů kostí ruky (obr. 1). Alternativní metodou ke stanovení fáze růstu je hodnocení krčních obratlů z kefalogramu [6] (obr. 2).

Rekonstrukce chrupu náhradami nesenými implantáty je podmíněna multidisciplinární spoluprací stomatochirurga, protetika a ortodontisty. Úspěšná léčba jedince závisí nejen na funkční, ale také na psychosociální adaptaci. Kvalita života je výrazně ovlivněna spokojeností či nespokojeností se zubním ošetřením. Obavy pacienta souvisí primárně s jeho subjektivními i objektivními pocity, s funkcí náhrady i její estetikou.

Cíle studie byly tedy dva. Za prvé zhodnotit dlouhodobou léčbu dospívajících/mladých dospělých pacientů po multidisciplinární léčbě, včetně zavedení implantátů s CAD CAM protetickou rekonstrukcí chrupu. Za druhé vyhodnotit změny v kvalitě života před a po zavedení dentálního implantátu.

\section{MATERIÁL A METODY}

V prospektivní studii jsme posuzovali soubor 73 implantátů (Osseo Speed ${ }^{\mathrm{TM}}$ ASTRA TECH Implant System $^{\top M}$ ). Hodnotili jsme skupinu adolescentů a mladých dospělých ve věkovém rozmezí 16 až 23 let (13 mužů a 20 žen; průměrný věk byl 20,4 let) (tab.1). Pacienti byli sledováni po dobu šesti let. Kontrolovali jsme jejich estetický vzhled se zaměřením na tvar a polohu korunek i vývoj rekonstrukce na základě pacientovy hygieny a parodontálního biotypu (silný, slabý). V RTC obrazu jsme hodnotili polohu mikrozávitů v krčkové oblasti implantátů Astra vzhledem $\mathrm{k}$ výšce okolní kosti, tedy změnu oseointegrace implantátu $z$ hlediska apozice či resorpce kosti.

Pacienti zařazení do studie anonymně vyplnili dotazník zjištující kvalitu života, který byl zaměřen na jejich orální zdraví a byl vytvořen na základě dotazníku Geriatric Oral Health Assessment Index [3]. Jde o validovaný dotazník zabývající se kvalitou života u pacientů se ztrátou vlastních zubů, a je proto využíván pro účely implantologie [10]. Obsahoval 12 následujících otázek cílených na: ukusování potra-

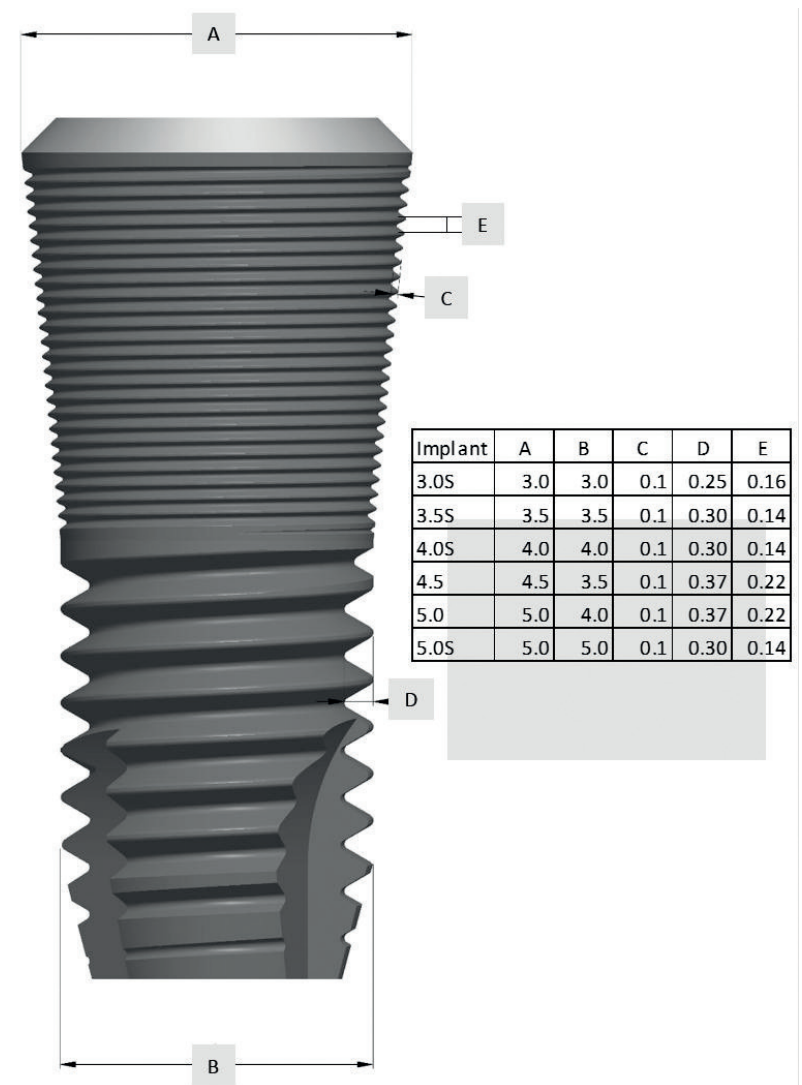

Obr. 3 Tvary a velikosti implantátu Osseo SpeedTM ASTRA TECH Implant SystemTM (obrázek vytvořen autory podle produktového katalogu ASTRA TECH - http://www.dentsplyimplants.com/ /media/M3\%20Media/DENTSPLY\%20 IMPLANTS/Product/1207012\%20Product\%20 catalog. ashx?filetype

vy; rozmělňování/žvýkání potravy; vnímání chuti; subjektivní vjemy během jídla; pocity při komunikaci na veřejnosti; omezení v druzích a množství jídla; mluvení a artikulaci. Dotýkal se společenského života; zjištoval, zda pacient/ka má citlivé zuby či problémy v oblasti parodontu; zda je spokojený/á se svým vzhledem; zda měl/a problémy při výkonu povolání a zda všechny komplikace snížily jeho celkovou kvalitu života.

Pacienti odpovídali na jednotlivé otázky podle pětistupňové Likertovy škály v rozmezí: 1 = „vždy“, 2 = „často“, 3 = „někdy“, 4 = „žrídka“, 5 = „nikdy“. Porovnali jsme jednotlivé výsledky dotazníku zazna-

Tab. 1 Soubor 73 implantátů Osseo SpeedTM ASTRA TECH Implant SystemTM

\begin{tabular}{|l|l|l|l|l|l|l|l|l|l|l|l|l|l|l|l|}
\hline & 7 & 6 & 5 & 4 & 3 & 2 & 1 & 1 & 2 & 3 & 4 & 5 & 6 & 7 & \\
\hline HORNÍ ČELIST & 1 & 4 & 2 & 2 & 2 & 4 & 3 & 5 & 7 & 3 & 5 & 8 & 6 & 1 & 53 \\
\hline DOLNÍ ČELIST & 2 & 3 & 3 & 1 & 0 & 2 & 1 & 0 & 2 & 1 & 0 & 3 & 2 & 0 & 20 \\
\hline CELKEM & 3 & 7 & 5 & 3 & 2 & 6 & 4 & 5 & 9 & 4 & 5 & 11 & 8 & 1 & 73 \\
\hline
\end{tabular}


menané před implantací a po ní, které byly následně vyhodnoceny pomocí Wilcoxonova párového testu. Za statisticky významné byly považovány hodnoty $\mathrm{p}<0,05$. Byl dále využit 95\% interval spolehlivosti pro střední hodnotu rozdílu ve skóre po implantaci a před implantací.

Studie se uskutečnila u pacientů ošetřených na oddělení Stomatologické kliniky dětí a dospělých 2. LF UK a FN Motol v Praze v období od října 2007 do března 2013 se souhlasem etické komise Fakultní nemocnice $v$ Motole. Informované souhlasy byly získány od všech ošetřených před zahájením léčby. Pacienti zařazení do studie museli splňovat následující kritéria: absence celkových nebo lokálních onemocnění, výborná ústní hygiena, sanovaný chrup, dostatečné množství a kvalita kosti umožňující zavedení implantátu či augmentaci a ztrátu jednoho až tří stálých zubư. Každý jedinec zařazený do studie absolvoval iniciální terapii orální hygieny. Zavedení implantátu bylo možné, až když pacient v opakovaných kontrolních vyšetřeních prokázal výbornou ústní hygienu.

K implantaci byly použity implantáty ASTRA TECH Single Tooth Implant o délce 11-13 mm a šířce 3,0-5,0 mm, které jsou opatřeny v krčkové části mikrozávity (MicrothreadTM. Ltd., UK). Každý implantát má takových mikrozávitů 25, ale výška každého mezi dvěma mikrozávity je ve vztahu k délce implantátu různá (obr. 3).

Před zavedením dentálního implantátu byly všichni pacienti klinicky vyšetřeni, byl zhotoven CT a OPG snímek. U mladých pacientů a adolescentů byly provedeny RTC snímky zápěstí a ruky nebo kefalometrický snímek páteře k zhodnocení ukončení vývoje a růstu, který je součástí telerentgenu. Implantace probíhala podle všech daných standardů. Po vhojovací době tří měsíců v dolní čelisti a šesti měsícư v horní čelisti, proběhla druhá fáze implantace. Definitivní protetické práce byly zhotoveny metodou CAD-CAM (Prettau ${ }^{\circledR}$ Zirconia, (Zirkonzahn, GmbH, Gais, Itálie) a BioCam (Lasak, s.r.o., ČR) a definitivně odevzdány tř̀i týdny po druhé fázi.
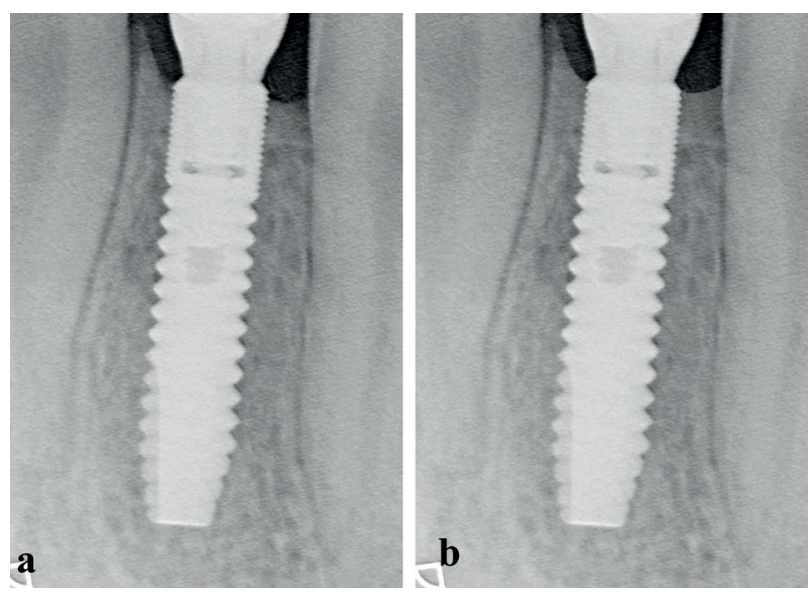

PRAKTICKÉ ZUBNÍ LÉKAŘSTVí, ročník 63, 2015, 4, S. $45-52$
Obr. 4 Změna oseointegrace po pěti letech od implantace (přírůstek: +2 mikrozávity = implantát 4 OS $-2 \times 0,14 \mathrm{~mm}=0,28 \mathrm{~mm}$ přírůstek kosti)

Dohromady bylo zavedeno 73 implantátů Astra Tech Dental Implants (53 v maxile, $20 \mathrm{v}$ mandibule).

Klinické vyšetření probíhalo každých šest měsíců. Hodnotili jsme stav orální hygieny, stav sliznic v okolí implantátu, bolest v okolí implantátu, stabilitu, protetické suprakonstrukce a oseointegraci implantátů prostřednictvím intraorálních RTC snímků. Intraorální RTG snímky (Gendex EXPERT ${ }^{\circledR}$ DC, with VistaScan Mini image plate scanner. KaVo Dental GmbH, Biberach, SRN) jsme zhotovili vždy po zavedení implantátu, nasazení suprakonstrukce a opakovaně během kontrolních vyšetření v průběhu šestileté periody. U každého pacienta byla zhotovena také fotodokumentace.

Oseointegrace implantátů, tedy změna kostní hmoty v okolí krčku implantátů, byla hodnocena na základě srovnání intraorálních RTG snímků získaných z opakovaných klinických vyšetření. Změna kostní hmoty se projevila vždy v oblasti mikrozávitů, jejichž rozměr jsme si předem změřili. Samotné měření probíhalo na RTG snímku srovnáním dvou bodů - referenčního bodu a nejnižšího pozorovaného bodu, kde docházelo ke kontaktu marginální

Tab. 2 Změna oseointegrace

\begin{tabular}{|c|c|c|}
\hline Průměr fixtury v $\mathbf{( m m})$ & Změna oseointegrace $\mathbf{( m m )}$ & Standardní odchylka měření (mm) \\
\hline 3.0 & $+0,34$ & 0,40 \\
\hline 3.5 & $+0,29$ & 0,47 \\
\hline 4.0 & $+0,09$ & 0,33 \\
\hline 4.5 & $+0,40$ & 0,33 \\
\hline 5.0 & $-0,10$ & $\mathbf{0 , 3 5}$ \\
\hline $\begin{array}{l}\text { Celkem } \\
\text { (Jedná se o průměry z neagregovaných dat) }\end{array}$ & $\mathbf{0 , 1 7}$ & $\mathbf{0}$ \\
\hline
\end{tabular}




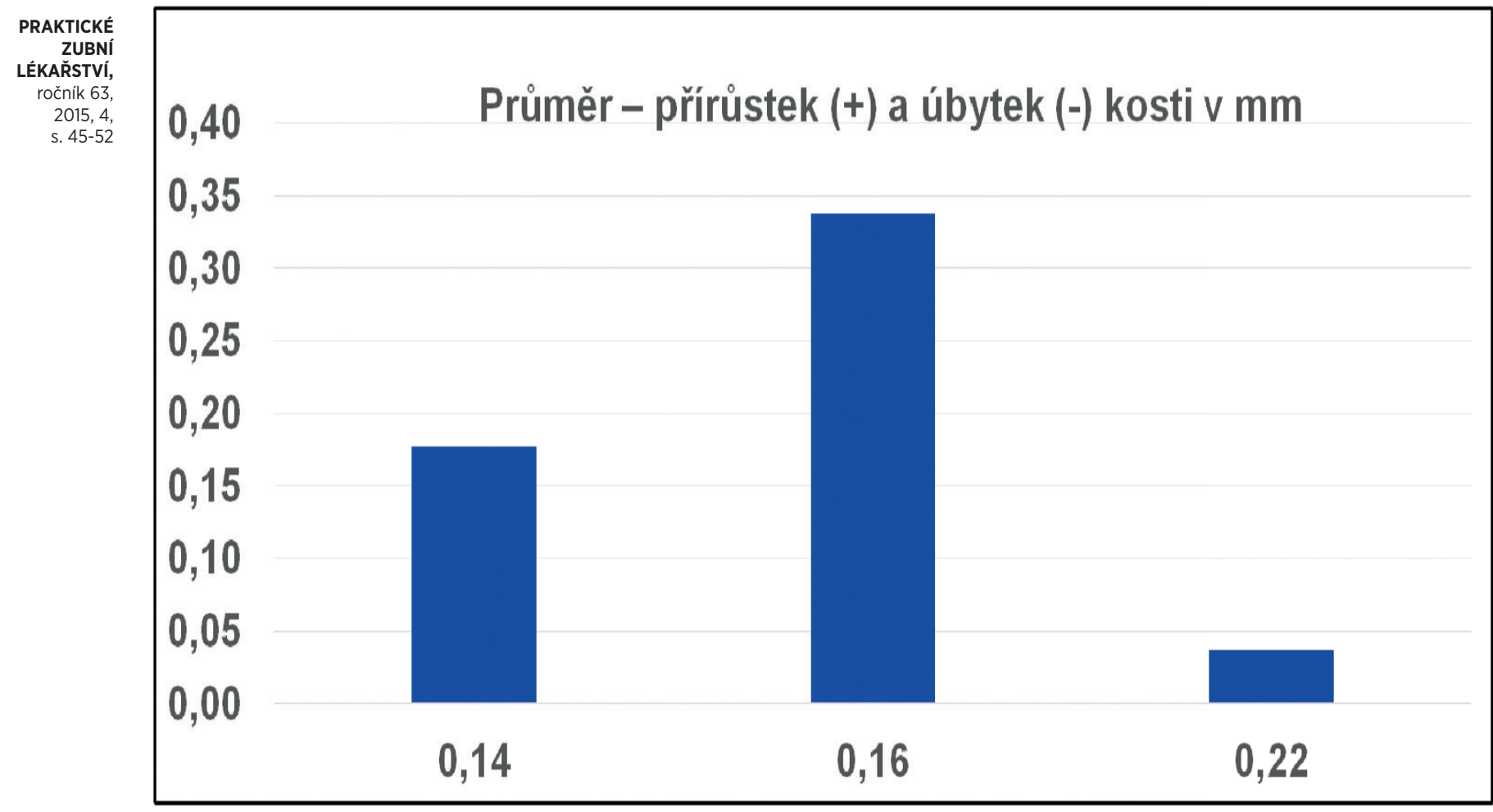

Graf 1 Vliv výšky mikrozávitu na kvalitu oseointegrace (stoupání mikrozávitu implantátů v mm)

kosti s povrchem fixtury. Referenčním bodem byla zvolena hranice mezi mechanicky opracovaným povrchem fixtury a titanium oxide-blasted povrchem. Změnu kostní hmoty jsme vypočítali v [mm] (obr. 3, 4).

\section{VÝSLEDKY}

Náš soubor se skládal ze 73 implantátů (tabulka 1), které nahrazovaly zuby ztracené úrazem (25), anodoncií (24), retencí a následnou extrakcí (pětkrát) i kazem a jeho komplikacemi (19).

Dlouhodobě jsme při pravidelných kontrolních vyšetřeních nezaznamenali žádné významné komplikace $z$ hlediska integrace implantátů a jejich suprastruktur, tedy žádný pacient si nestěžoval na bolest, nezjistili jsme pohyb v oblasti implantátů. Pacienti byli spokojeni s protetickou rehabilitací chrupu. Neobjevila se výrazná změna ve tvaru a poloze měkkých tkání v okolí implantátu. Kompromisní řešení tvaru a velikosti korunek bylo vzhledem $\mathrm{k} 3 \mathrm{D}$ zavedení implantátů v $18 \%$ př́padů.

$\mathrm{K}$ apozici kosti došlo $\mathrm{v}$ rozmezí $+0,34 \mathrm{~mm}$ (SD $0,40)$ ( tři mm průměr implantátu) do $+0,40$ (SD 0,33 ) (4,5 mm průměr implantátu) (tab. 2, obr. 4). U implantátu o průměru $5 \mathrm{~mm}$ došlo $\mathrm{k}$ resorpci $-0,10 \mathrm{~mm}$ (SD 0,25). Prokázali jsme, že šířka implantátů i výška mikrozávitů má statisticky významný vliv na apozici či resorpci kosti při oseointegraci implantátu Astra u mladých pacientů (graf 1). Nejsilnější implantáty (o průměru pět $\mathrm{mm}$ ), měly dlouhodobě větší resorpci slabší kosti (1-1,5 mm) obkružující oblast krčkového uzávěru. Tato změna nebyla statisticky významná.

Závěry získané z odpovědí na 11 otázek dotazníku prokázaly signifikantně zlepšenou kvalitu života po implantaci $(\mathrm{p}<0,05)$. Optimálních výsledkư z hlediska funkce i estetiky bylo dosaženo u mladých pacientů s implantáty zavedenými po traumatu. Tato skupina pacientů se zpravidla vyznačovala ztrátou některého $\mathrm{z}$ viditelného úseku chrupu zubư horní čelisti. Výjimku tvořilo hodnocení chuti, která se pochopitelně nemění $(p=0,389)$. Výsledky byly statisticky významné (tab. 3).

\section{DISKUSE}

S hypodoncií, anodoncií, oligodoncií a traumatickými ztrátami zubů se u dětských pacientů setkáváme často. V současnosti se stále více objevují i ztráty zubů způsobené kazem a jeho komplikacemi především v oblasti prvních molárů. Rehabilitace chrupu implantáty u mladých pacientů a adolescentů je indikována až po ukončení vývoje a růstu čelistí. Použití podmíněně snímatelných náhrad je metodou 
volby přinášející ovšem rizika v podobě zvýšeného výskytu zubního kazu, resorpce kosti alveolárního výběžku, ohrožení parodontu [12]. Náhrada vlastních zubů implantáty má zásadní význam pro klinickou praxi, kdy tvoří alternativu k ortodontickému ošetření, autotransplantaci či konvenčnímu protetickému řešení. Úspěšné dlouhodobé výsledky závisí především na stabilitě kostní tkáně obkružující implantát, tedy stejné nebo se zvyšující výšce kosti v oblasti krčkového uzávěru.

Z naší studie je zřejmé, že apozice nebo resorpce přímo souvisí s horizontální šířkou vrstvy kosti, která obklopuje implantát. Implantáty o užším průměru 3-4,5 mm, které jsou cirkulárně obklopeny 2-3mm vrstvou kostí, vykázaly statisticky významný nárůst kostní hmoty. Rentgenové snímky byly nejdůležitějším zdrojem po vyhodnocení změny kostní hmoty v okolí krčku fixtury [16]. Albrektsson a kol. stanovili kritéria pro úspěšně integrovaný implantát, kdy během prvního roku dochází k úbytku kostní hmoty $\mathrm{v}$ rozsahu $<1-1,5 \mathrm{~mm}$ a v následujících letech maximálně v rozsahu $<0,2 \mathrm{~mm}$ [12]. Z longitudinální patnáctileté studie integrace implantátů využívající systém Branemark byl zjištěn úbytek kostní hmoty v prvním roce po zavedení implantátu 1,2 mm [1]. Finite Element Analysis potvrzuje naše klinické závěry, že užší implantát prưměru menší než 4,5 mm, redukuje stresové zatížení, a nedochází tak k výraznému úbytku kosti [13]. Velký význam také doznala povrchová úprava fixtury. Lee a kol. ve tř́ileté studii prokázali, že u implantátů se systémem microthreads dochází k menšímu úbytku kosti v okolí krčku zatíženého implantátu [11]. Použití fixtur se systémem microthreads v naší studii u ošetřovaných s diagnózou ageneze či ztráty zubů po úrazu vedlo $z$ dlouhodobého hlediska u části pacientů k přírůstku kosti v okolí krčku implantátu. Prokázali jsme, že zásadní vliv na oseintegraci má nejen tvar implantátu, ale i síla kosti, která ho obkružuje. Paradoxně tedy nejsilnější implantáty o prưměru $5 \mathrm{~mm}$, mají dlouhodobě větší resorpci kosti v oblasti krčkového uzávěru. Tento výsledek však nebyl statisticky významný.

Zhotovení suprakonstrukce, podporované CADCAM technologií, přinesly nejlepší výsledky ve funkci a estetice, a tato technika je také velmi dobře akceptovaná pacienty [5]. Z naší studie také vyplývá, že vhodný věk pro zavedení implantátu nelze přesně stanovit. K zavedení dentálního implantátu ale musí být nezbytně splněna podmínka ukončeného vývoje skeletu a čelistí (hodnotíme na základě RTC zápěstí a ruky nebo kefalometrického snímku páteře u ortodontických pacientů). Nedodržení těchto podmínek vede později k selhání implantátu. S korekcí většiny ortodontických anomálií u mladých pacientů je proto lépe vyčkat a koordinovat je ve vztahu k aplikaci implantátů.

Úspěšná rekonstrukce chrupu je podmíněna nejen úspěšnou oseointegrací implantátů, ale také psychosociální a funkční adaptací pacienta. Kvalita života je výrazně ovlivněna spokojeností či nespokojeností se zubním ošetřením. V prvé řadě obavy

Tab. 3 P-hodnoty jsou korigovány pro vícenásobné porovnávání podle postupu Holm’s step-down. Rozdíly byly vypočteny odečtením mezi QoL skóre odpovědi pacienta s implantátem a bez implantátů pro všechny otázky. 95\% intervaly spolehlivosti pro průměrný rozdíl Qol pacienta s implantátem a bez implantátů byly vypočteny pomocí metody bootstrapping

\begin{tabular}{|c|c|c|}
\hline $\begin{array}{l}\text { Otázky z dotazníku kvality života } \\
\text { pacientů (QoL) s dentálními implantáty }\end{array}$ & $\begin{array}{l}\text { p-hodnota (Wilcoxon } \\
\text { signed-rank tests1) }\end{array}$ & $\begin{array}{l}\text { 95\% interval spolehlivosti pro střední } \\
\text { hodnotu rozdílu před implantací a po im- } \\
\text { plantaci ( } 95 \% \mathrm{Cl} \text { for mean of differences } \\
\text { in QoL scores w/i and w/o implants) }\end{array}$ \\
\hline Obtížné ukusování potravy & $<0,001$ & $1,364(0,899 ; 1,816)$ \\
\hline Obtížné rozmělňování/žvýkání potravy & $<0,001$ & $1,242(0,791 ; 1,737)$ \\
\hline Obtížné vnímání chuti & 0,389 & $0,091(-0,158 ; 0,346)$ \\
\hline Nepřijemný pocit během jídla & $<0,001$ & $1,303(0,896 ; 1,688)$ \\
\hline Nepříjemné jedení na veřejnosti & $<0,001$ & $1,576(1,095 ; 2,067)$ \\
\hline Omezený druh a množství jídla & $<0,001$ & $0,879(0,524 ; 1,246)$ \\
\hline Obtižné mluvení a artikulace & 0,009 & $0,485(0,181 ; 0,810)$ \\
\hline Omezené setkávání s lidmi & 0,012 & $0,394(0,136 ; 0,631)$ \\
\hline Citlivé zuby a dásně na teplé anebo studené & $<0,001$ & $0,606(0,301 ; 0,898)$ \\
\hline Nespokojený/á se svým vzhledem & $<0,001$ & $2,091(1,681 ; 2,524)$ \\
\hline Měl jsem kvưli svým problémům potiže při výkonu povolání & 0,020 & $0,333(0,086 ; 0,571)$ \\
\hline Mé obtiže naprosto snižují celkovou kvalitu mého života & $<0,001$ & $1,030(0,681 ; 1,418)$ \\
\hline
\end{tabular}


pacientů souvisí s funkční a estetickou rehabilitací chrupu. Nesplnění těchto podmínek vyvolá u pacienta psychické změny ve formě sníženého sebevědomí, úzkosti, nejistoty, introverze. Významné rozdíly v mastikaci, řeči, estetice, vnímání sebe sama byly zjištěny srovnáním ošetření pomocí konvenčních celkových náhrad oproti dentálním implantátům [4]. Heydecke a kol. prokázali, že bezzubá čelist má negativní dopad na sociální a sexuální život [7]. Naše studie prokázala, že vnímaní estetiky, funkce, at již rozmělňování potravy, nebo fonace, prímo souvisí s rehabilitací chrupu včetně zavedení implantátů. Subjektivní spokojenost pacienta měla přímý vliv na zlepšení celkové kvality života jak osobního, tak společenského i pracovního. Co je neměnné, je vnímání chuti, které s celkovou funkční rekonstrukcí pochopitelně nesouvisí.

\section{ZÁVĔR}

Dentální implantologie je neustále se rozvíjející obor. Použití dentálních implantátů u adolescentních pacientů k rehabilitaci ztracených stálých zubů má i v dnešní době určitá omezení. Dưraz u mladých pacientů musí být kladen na ukončení vývoje obličejového skeletu a na individuální provedení suprastruktur za použití CAD CAM technik. Pokud se rozhodneme zavést dentální implantát $u$ adolescentního pacienta, pak by sestavení léčebného plánu mělo probíhat na multidisciplinární úrovni mezi ortodontistou, stomatochirurgem, protetikem a někdy také psychologem.

\section{LITERATURA}

1. Adell, R., Lekholm, U., Rocker, B., Branemark, P. I.: A 15-years study of osseointegrated implants in the treatment of the edentulous jaw. Int. J. Oral Surg., roč. 10, 1981, č. 6, s. 387-416.

2. Albrektsson, T., Zarb, G., Worthington, P., Eriksson, R. A.: The longterm efficacy of currently used dental implants. A review and proposed criteria for success. Int. J. Oral Maxillofac. Implants, roč. 1, 1986, č. 1, s. 11-25.

3. Atchison, K. A., Dolan, T. A.: Development of the geriatric ora health assessment index. J. Dent. Educ., roč. 54, 1990, č. 11, s. 680687.

4. Cibirka, R. M., Razzoog, M., Lang, B. R.: Critical evaluation of patient responses to dental implant therapy. J. Prosthet. Dent., roč. 78, 1997, č. 6, s. 574-581.

5. Fuster-Torres, M. A., Albalat-Estela, S., Alcañiz-Raya, M., Peñarrocha-Diago, M.: CAD / CAM dental systems in implant dentistry: update. Med. Oral Patol. Oral Cir. Bucal., roč. 14, 2009, č. 3, s. 141-145.
6. Hassel, B., Farman, A. G.: Skeletal maturation evaluation using cervical vertebrae. Am. J. Orthod. Dentofacial Orthop., roč. 107, 1995, č. 1, s. 58-65.

7. Heydecke, G., Thomason, J. M., Lund, J. P., Feine, J. S.: The impact of conventional and implant supported prostheses on social and sexual activities in edentulous adults. Results from a randomized trial 2 months after treatment J. Dent., roč. 33, 2005, č. 8, s. 649-657.

8. Iseri, H., Solow, B.: Continued eruption of maxillary incisors and first molars in girls from 9 to 25 years, studies by the implant method. Eur. J. Orthod., roč.18, 1996, č. 3, s. 246-256.

9. Krasnicanova, H., Lesny, P.: Kompendium pediatricke Auxologie. Čes.-slov. Pediat. 2001, č. 7, s. 412-416.

10. Kř́žž, P., Seydlova, M., Dostalova, T., Valenta, Z., Chleborad, K., Zvarova, J., Feberova, J., Hippmannn, R.: Dental implants and improvement of oral health-related quality of life Community. Dent. Oral Epidemiol., roč. 40, 2012, Suppl. 1, s. 65-70.

11. Lee, D. W., Choi, Y. S., Park, K. H., Kim, C. S., Moon, I. S.: Effect of microthread on the maintenance of marginal bone level: a 3-year prospective study. Clin. Oral Implants Res., roč. 18, 2007, č. 4, s. 465-470.

12. Mishra, S. K., Chowdhary, N., Chowdhary, R.: Dental implants in growing children, J. Indian Soc. Pedod. Prev. Dent., roč. 31, 2013, č. 1, s. 3-9.

13. Schrotenboer, J., Tsao, Y. P., Kinariwala, V., Wang, H. L.: Effect of microthreads and platform switching on crestal bone stress levels: a finite element analysis. J. Periodontol., roč. 79, 2008, č. 11, s. 2166-2172

14. Tanner, J. M., Whitehouse, R. H., Cameron, N., Marshall, W. A., Healy, M. J. R.: Assessment of skeletal maturity and prediction of adult height (TW2 Method). Goldstein H. ed., 2nd ed. London, UK: Academic Press, 1983.

15. Thilander, B., Odman, J., Jemt, T.: Single implants in the upper incisor region and their relationship to the adjacent teeth. An 8-year follow-up study. Clin. Oral Implants Res., roč. 10, 1999, č. 5, s. 346-55.

16. Verhoeven, J. W., Cune, M. S., de Putter, C.: Reliability of some clinical parameters of evaluation in implant dentistry. J. Oral Rehabil., roč. 27, 2000, č. 3, s. 211-216.

Autoři děkují statistikovi RNDr. Alexi Vinšů za spolupráci při tvorbě modelu implantátu.

Studie byla podporována projektem IGA MZČR číslo 13351-4. 